\title{
Publisher Correction to: Insights into the demographic history of Asia from common ancestry and admixture in the genomic landscape of present-day Austroasiatic speakers
}

Debashree Tagore ${ }^{1}$, Farhang Aghakhanian ${ }^{2,3}$, Rakesh Naidu ${ }^{4}$, Maude E. Phipps ${ }^{4}$ and Analabha Basu ${ }^{*}$

Publisher Correction to: BMC Biol 19, 61 (2021)

https://doi.org/10.1186/s12915-021-00981-x

Following publication of the original article [1], an error was identified in the 'Availability of data and materials' section due to a typesetting mistake: in the first sentence of this section, a citation to reference 76 was present, instead of a citation to reference 72 .

The original article [1] has been updated. The publisher apologises to the authors and readers for the inconvenience caused by this mistake.

\section{Author details}

${ }^{1}$ National Institute of Biomedical Genomics, Kalyani 741251, India. ${ }^{2}$ Oklahoma Medical Research Foundation, Genes and Human Disease Program, 825 NE 13th Street, Oklahoma City, OK 73104, USA. ${ }^{3}$ Genomics Facility, School of Science, Monash University Malaysia, Jalan Lagoon Selatan, 47500 Bandar Sunway, Selangor, Malaysia. ${ }^{4}$ Jeffrey Cheah School of Medicine and Health Sciences, Monash University Malaysia, Jalan Lagoon Selatan, 47500 Bandar Sunway, Selangor Darul Ehsan, Malaysia.

Published online: 04 November 2021

\section{Reference}

1. Tagore, et al. Insights into the demographic history of Asia from common ancestry and admixture in the genomic landscape of present-day Austroasiatic speakers. BMC Biol. 2021;19:61. https://doi.org/10.1186/s12915021-00981-x.

The original article can be found online at https://doi.org/10.1186/s12915021-00981-x

* Correspondence: ab1@nibmg.ac.in

${ }^{1}$ National Institute of Biomedical Genomics, Kalyani 741251, India

Full list of author information is available at the end of the article

\section{Publisher's Note}

Springer Nature remains neutral with regard to jurisdictional claims in published maps and institutional affiliations.

() The Author(s). 2021 Open Access This article is licensed under a Creative Commons Attribution 4.0 International License, which permits use, sharing, adaptation, distribution and reproduction in any medium or format, as long as you give appropriate credit to the original author(s) and the source, provide a link to the Creative Commons licence, and indicate if changes were made. The images or other third party material in this article are included in the article's Creative Commons licence, unless indicated otherwise in a credit line to the material. If material is not included in the article's Creative Commons licence and your intended use is not permitted by statutory regulation or exceeds the permitted use, you will need to obtain permission directly from the copyright holder. To view a copy of this licence, visit http://creativecommons.org/licenses/by/4.0/ The Creative Commons Public Domain Dedication waiver (http://creativecommons.org/publicdomain/zero/1.0/) applies to the data made available in this article, unless otherwise stated in a credit line to the data. 